\title{
The use of phosphorus oxychloride in the synthesis of amino acid $p$-nitroanilides
}

Citation for published version (APA):

Rijkers, D. T. S., Hemker, H. C., Nefkens, G. H. L., \& Tesser, G. I. (1991). The use of phosphorus oxychloride in the synthesis of amino acid $\mathrm{p}$-nitroanilides. Recueil des Travaux Chimiques des Pays-BasJournal of the Royal Netherlands, 110(7-8), 347-348. https://doi.org/10.1002/recl.19911100709

Document status and date:

Published: 01/01/1991

DOI:

10.1002/recl.19911100709

Document Version:

Publisher's PDF, also known as Version of record

\section{Please check the document version of this publication:}

- A submitted manuscript is the version of the article upon submission and before peer-review. There can be important differences between the submitted version and the official published version of record.

People interested in the research are advised to contact the author for the final version of the publication, or visit the DOI to the publisher's website.

- The final author version and the galley proof are versions of the publication after peer review.

- The final published version features the final layout of the paper including the volume, issue and page numbers.

Link to publication

\footnotetext{
General rights rights.

- You may freely distribute the URL identifying the publication in the public portal. please follow below link for the End User Agreement:

www.umlib.nl/taverne-license

Take down policy

If you believe that this document breaches copyright please contact us at:

repository@maastrichtuniversity.nl

providing details and we will investigate your claim.
}

Copyright and moral rights for the publications made accessible in the public portal are retained by the authors and/or other copyright owners and it is a condition of accessing publications that users recognise and abide by the legal requirements associated with these

- Users may download and print one copy of any publication from the public portal for the purpose of private study or research.

- You may not further distribute the material or use it for any profit-making activity or commercial gain

If the publication is distributed under the terms of Article $25 \mathrm{fa}$ of the Dutch Copyright Act, indicated by the "Taverne" license above, 


\title{
THE USE OF PHOSPHORUS OXYCHLORIDE IN THE SYNTHESIS OF AMINO ACID p-NITROANILIDES
}

\author{
D.T.S. Rijkers ${ }^{* 1}$, H.C. Hemker ${ }^{1}$, G.H.L. Nefkens * and G.I. Tesser * \\ * Catholic University of Nijmegen, Department of Organic Chemistry, Toernooiveld, \\ 6525 ED Nijmegen, The Netherlands \\ ${ }^{1}$ University of Limburg, Faculty of Medicine, Department of Biochemistry, P.O. Box \\ 616, 6200 MD Maastricht, The Netherlands \\ (Received June 13th, 1991)
}

\begin{abstract}
Phosphorus oxychloride is described as a condensing agent in the preparation of nitroanilides. The condensation was free of racemization with amino acid derivatives of the urethane type and the current amino protective groups can be applied. The yields are high to excellent.
\end{abstract}

Amino acid p-nitroanilides are widely used as chromogenic substrates for the determination of the activity of proteolytic enzymes ${ }^{1}$. The synthesis of p-nitroanilides is rather difficult because of the low nucleophilicity of $\mathrm{p}$-nitroaniline. The coupling methods used in peptide synthesis are for this reason inadequate ${ }^{2}$. The most frequently applied methods involve use of phosphorus trichloride (the phosphorazo-method) ${ }^{3}$ or phosphorus pentoxide in diethyl phosphite ${ }^{4}$. With these methods the obtained yields vary between 30 $44 \%$. Of interest to us is arginine p-nitroanilide dihydrochloride, which can be used as a building block of e.g. chromogenic substrates. In the literature different syntheses of arginine p-nitroanilide are described ${ }^{5}$. These syntheses succeed only if protective groups were used, which are removable with strong acid.

Recently Noda et al. ${ }^{6}$ described for the first time the synthesis of tert- butyloxycarbonyl amino acid p-nitroanilides via the pivaloyl mixed anhydride method. However, the synthesis of the arginine-derivative is not described. More recently Oyamada et al. ${ }^{7}$ described the synthesis of tert- butyloxycarbonyl-arginine p-nitroanilide with the phosphorazo-method. This is the first

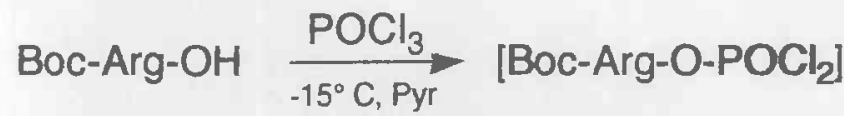

time that the synthesis of a p-nitroanilide has been described in which the $\alpha$-amino function is protected with a tert- butyloxycarbonyl group.

With the use of phosphorus oxychloride ${ }^{8}$ in the synthesis of p-nitroanilides ${ }^{9}$ nearly all protected amino acids can be used with virtually every $\alpha$ amino protective group. We want to stress the usefulness of phosphorus oxychloride in the synthesis of $\mathrm{N}$-protected arginine p-nitroanilide. We synthesized the hydrochlorides of Boc- (m.p. $\left.187^{\circ} \mathrm{C}, \alpha_{\mathrm{D}}-12.8^{\circ}, \mathrm{c}=1 \mathrm{MeOH}\right), \mathrm{Z}-\left(\right.$ m.p. $174^{\circ} \mathrm{C}$, $\alpha_{D}-7.7^{\circ}, \mathrm{c}=1 \mathrm{DMF}$ ) and Fmoc- (m.p. $96^{\circ} \mathrm{C}$ (dec), $\left.\alpha_{\mathrm{D}}-37.2^{\circ}, \mathrm{c}=1 \mathrm{DMF}\right)$ arginine $\mathrm{p}$-nitroanilides in high yield (90-95\%) and in an optical pure form ${ }^{10}$. In a typical procedure, (scheme) an $\alpha$ protected amino acid $(10 \mathrm{mmol})$ and p-nitroaniline $^{11}$ (10 mmol) were dissolved in dry pyridine $^{12}(30 \mathrm{ml})$. The clear yellowish solution was cooled to $-15^{\circ} \mathrm{C}$ and phosphorus oxychloride $(11 \mathrm{mmol})$ was added dropwise with vigorous stirring. During the addition the reaction mixture turned deep red and became turbid in the course of $15 \mathrm{~min}$. The colour of the suspension slowly changed to orange, the reaction being complete after a total of $30 \mathrm{~min}$ (monitored by TLC). The reaction mixture was then quenched with crush-

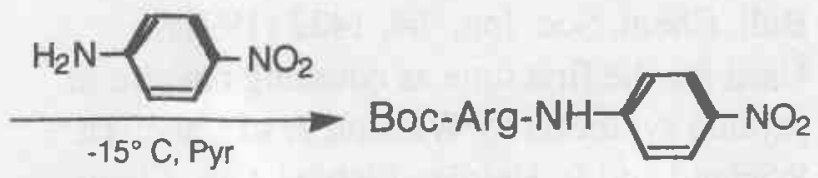


ed ice and water $(100 \mathrm{ml})$ and the nitroanilide was extracted into EtOAc. The combined EtOAc-layers were washed with saturated $\mathrm{NaHCO}_{3}$ and $\mathrm{NaCl}$ solutions. The EtOAc-layer was not dried, to prevent premature crystallization and was directly evaporated in vacuo. The residue was coevaporated successively with toluene, EtOAc and $\mathrm{MeOH}$ to remove residual pyridine. To remove unreacted p-nitro-aniline, the crude reaction product was suspended in diethyl ether and filtered. The residue was subsequently recrystallized from a convenient solvent. With this method the following protected amino acid p-nitroanilides were synthesized in high yield (circa 90\%) and in an optically pure form: Ala, Gly, Phe, Asp $\left(\mathrm{OBu}^{t}\right), \quad \mathrm{Glu}\left(\mathrm{OBu}^{t}\right)$, Lys(Boc) and $\operatorname{Arg}(\mathrm{HCl})$.

We conclude that Wielands method ${ }^{8}$ for carboxyl activation constitutes the method of choice for synthesis of amino acid p-nitroanilides.

\section{References and notes:}

1. B.J. Haverback, B. Dyce and H.A. Edmondson, Am. J. Med. 29, 424 (1960); B.F. Erlanger, N. Kokowsky and W. Cohen, Arch. Biochem. Biophys. 95, 271 (1961); H.C. Hemker ed. "Handbook of Synthetic Substrates for the Coagulation and Fibrinolytic System" Martinus Nijhoff Publishers, Boston, (1983).

2. With these methods only low yields are obtained after unnecessary long reaction times.

3. S. Goldschmidt and G. Rosculet, Chem. Ber. 93, 2387 (1960).

4. G. Schramm and H. Wissmann, Chem. Ber. 91, 1073 (1958); B.F. Erlanger and N. Kokowsky, J. Org. Chem. 26, 2534 (1961).

5. E. Kasafirek, M. Chavko and M. Bartik, Coll. Czech. Chem. Commun. 36, 4070 (1971); O. Somorin, N. Nishi and J. Nogu chi, Bull. Chem. Soc. Jpn. 51, 1255 (1978).

6. K. Noda, M Oda, M. Sato and N. Yoshida, Int. J. Peptz e Protein Res. 36, 197 (1990).

7. H. Oyamada, T. Saito, S. Inaba and M. Ueki, Bull. Chem. Soc. Jpn. 64, 1422 (1991).

8. Used for the first time as coupling reagent in peptide synthesis by Wieland et al., see: Th. Wieland and B. Heinke, Liebigs Ann. Chem. 599, 70 (1956).
9. The synthesis of an amino acid p-nitroanilide with phosphorus oxychloride was for the first time carried out by one of us (G.I.T.) and recommended by $R$.J. Planta and $M$. Gruber, Biochim. Biophys. Acta 89, 503 (1964), who earlier obtained racemic Z-GlyPhe-pNA in a low yield by activation of ZGly-Phe-OH with $\mathbf{N}, \mathbf{N}$-dicyclohexylcarbodiimide, Anal. Biochem. 5, 360 (1963).

10. The optical rotations found correspond with those cited in the literature, see 7 . The behaviour of the p-nitroanilides synthesized by the method described here in enzymatic hydrolyses were catalogous to those obtained by other methods.

11. Recrystallized from toluene.

12. Pyridine was dried over $\mathrm{KOH}$-pellets. 